and is not yet completed. The following extract from the introductory observations will indicate the spirit in which it is written :- "A few are still dissatisfied with the arguments against the dualistic system, and continue to employ the atomic weights of Berzelius, or the equivalents of Gmelin; and among those who have adopted the new system of atomic weights and formulæ, there are many who have done so merely in a spirit of concession, and make a display of scepticism respecting its intrinsic value; others, on the contrary, push their faith to the extent of fanaticism, and give equal value to the essential and accessory parts of the system, or even cling to hypotheses that merely lean against it or have been discarded. They often speak on molecular subjects with as much dogmatic assurance as though they had actually realised the ingenious fiction of Laplace-had constructed a microscope by which they could detect the molecules, and observe the number, form, and arrangement of their constituent atoms, and even determine the direction and intensity of their mutual actions. These things, which have been offered merely as hypotheses more or less probable, and to be taken for what they are worth as simple artifices of the intellect, are valuable, and have done good service in collocating facts and inciting to further careful investigations that one day or other may lead to a true chemical theory; but when perverted by being stated as actual truths, they falsify the intellectual education of students of inductive science, and bring reproach upon the modern progress of chemical science."

We learned a great deal from Italy in the Middle Ages, and may yet learn more. I earnestly commend the above lesson to some of our laboratory aspirants, who are occupying themselves in ringing the changes upon organic compounds, and who afterwards describe their atomic achievements as glibly, mechanically, and confidently, as though they had been laying bricks or piling shot.

An interesting paper (a note it is modestly called) on "The Absorbent Power of Red Phosphorus" is contributed to the May number, by Fausto Sestini, from the Laboratory of the Royal Technical Institute of Udine. (Udine is a small town, smaller than Croydon, and situated about 70 miles N.E. of Venice. How many of such towns in England have Royal Technical Institutes with laboratories for original research?) The author finds that red phosphorus absorbs many substances without combining with them, after the manner of porous charcoal. Thus it may be made to take up 3.369 per cent. of iodine, a considerable quantity of sulphur, rosaniline, \&c. This power of "chemical adhesion" may be easily and strikingly shown by shaking powdered red phosphorus in a test tube containing a coloured solution of iodine in bisulphide of carbon. When a sufficient quantity of phosphorus is used, the whole of the iodine is taken up and the solvent rendered colourless. Rosaline is similarly removed from an etherial solution, and a portion of it may be again recovered unaltered from the phosphorus by washing with alcohol.

The July number contains some further contributions by Sestini from the same laboratory, on the proportions of bisulphide of carbon, its solubility in water, and the compounds formed by its contact with aqueous solutions of the oxides of the metals of the alkaline earths. Also some interesting communications from the laboratory of the University of Siena by Prof. G. Campani, among which is one showing that the absorption bands of an ammoniacal solution of carmine so closely coincide with those of blood, as to be undistinguishable in a spectroscope with a scale of twenty degrees. Mr. Sorby will probably be able to tell us whether any difference is distinguishable by more minute examination.

Lieben and Rossi contribute a series of rather important papers on some of the alcohols, and besides these there are some of the ordinary miscellaneous contributions to organic chemistry.

\section{THE CRYSTAL PALACE AQUARIUM}

T N NATURE of April 2o last appeared a short paragraph, stating that this "enterprise, of which great scientific use can certainly be made," was taking form, and that when some of the marine animals were introduced, and the thing was in working order, a description of it would be given.

The building undertaken by the Crystal Palace Aquarium Company was commenced in July 1870 , much too late therefore to be opened when at first contemplated, April I, I87 I, though at Easter last half a dozen of the marine tanks were temporarily converted into freshwater ones, and some pike, tench, carp, eels, \&c., were shown therein for three days; when the place was closed, and the progress of the works continued, and then the establishment was finally opened on August 22, 187 I. It would have been well if the sea-water had been in good condition in the early part of the summer, so that advantage might have been taken of the then exceptionally cool weather to transport some of the great abundance of animals at that time on the coasts of England; but that was not possible, and then, when the water was fit, the weather became very hot, and the sending of many animals was thereby prevented. Such creatures as could be got, however, were obtained, and the opportunity is now being taken of the present increasingly colder season to add other animals constantly, so that in a short time most of the tanks will be populated.

The accompanying plan, on page $47 \mathrm{I}$, drawn to a scale of about $50 \mathrm{ft}$. to I in., shows the ground occupied by the Aquarium and its adjuncts to be nearly 40oft. long and 7 oft. broad, and it is situated at the northern end of the Palace, on a portion of the site of it burnt in 1865 . It is of one story high, and, therefore, this ground plan shows everything, except the sea-water reservoir beneath the Saloon $G G$, extending under its whole width, and running below Tanks 9 and 10, and going lengthwise from E to H2. This reservoir contains 80,000 gallons of seawater, and the tanks above contain 20,000 gallons, in all I00,000, gallons weighing a million pounds; and the fact of the aggregate contents of the tanks being only one-fourth of the contents of the reservoir, is extremely serviceable in keeping the water clear, as, supposing the water in, say tank ro (holding 4,000 gallons), became turbid from any cause, it can be emptied by syphons in less than an hour into the reservoir, where so comparatively small a quantity of fluid would not appreciably disturb the purity of so great a mass, from which, in less than half an hour, No. ro can again be filled, and thus all the tanks where animals exist, are, by being constantly pumped into, day and night, from the large, clear, and cool reservoir below, where there are no creatures, kept ever in good order. The main aëration which is thus depended on for the health of the creatures, is by these means produced by mechanical agitation, and the quantity of sea-weed neces. sary to decompose the poisonous carbonic acid gas evolved from the animals, which could not be effected by mechanical agitation, is grown upon the rocks of the aquarium by the action of light on the spores of algæ existing invisibly in the water. As the motion of the water needs to be incessant, all the machinery is in duplicate, there being two boilers, each of four horse power, two steam-engines, each of three horse power, and two of Forbes's patent pumps, and one of each is kept ever in action, the other being in reserve in case of accident. The sea-water issuing from the pumps at the rate (indicated by a counter, while a tell-tale clock furnishes evidence of the attention of three enginemen, each working for eight consecutive hours) of from 5,000 to 7,000 gallons an hour, passes in the first place into the two highest tanks, 9 and Io, half into each, and from thence it runs, diverging north and south, as far as tanks 18 and $I$. From 18 it flows into 60 , and from I into 39 , in each case passing 

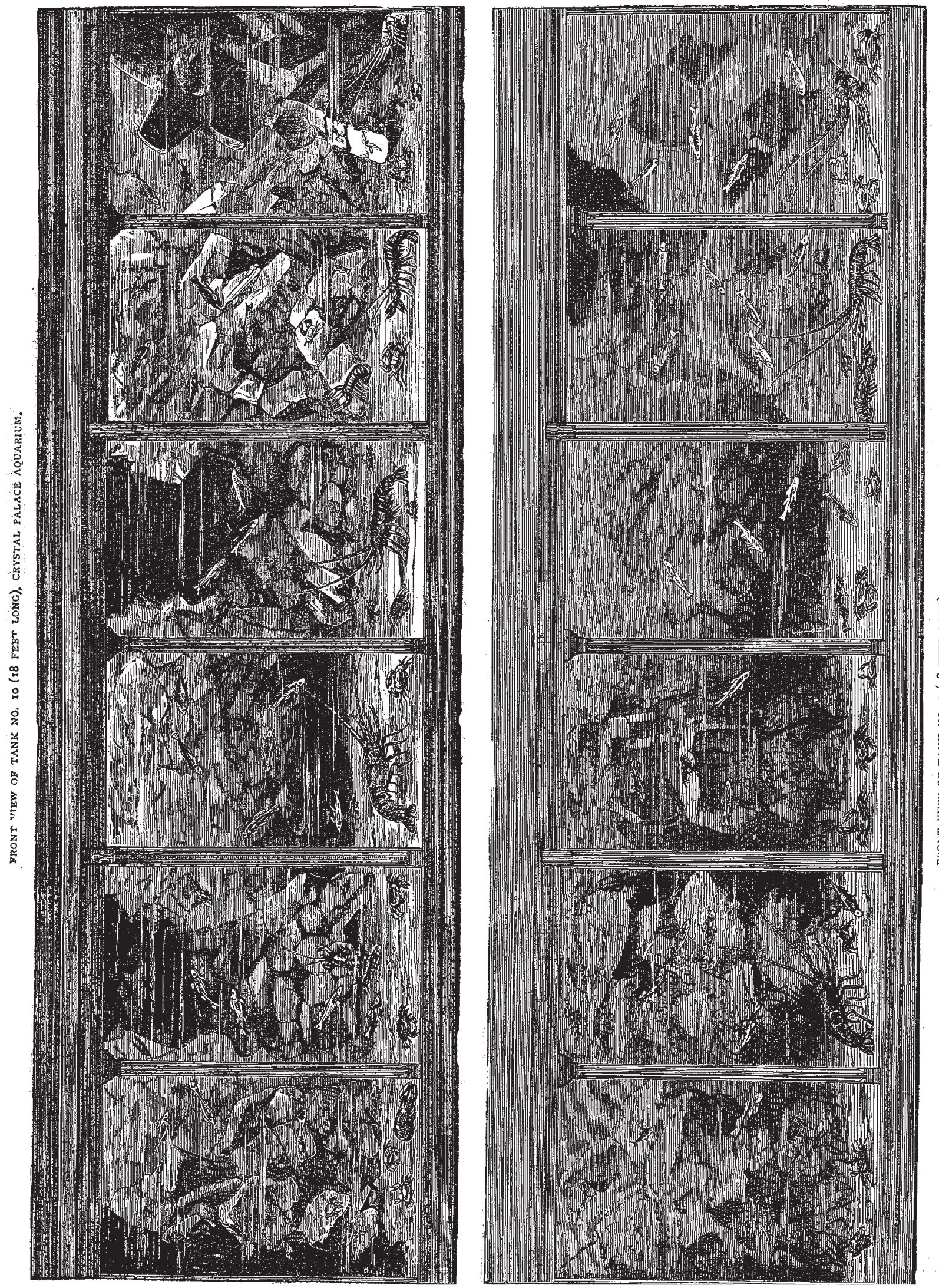


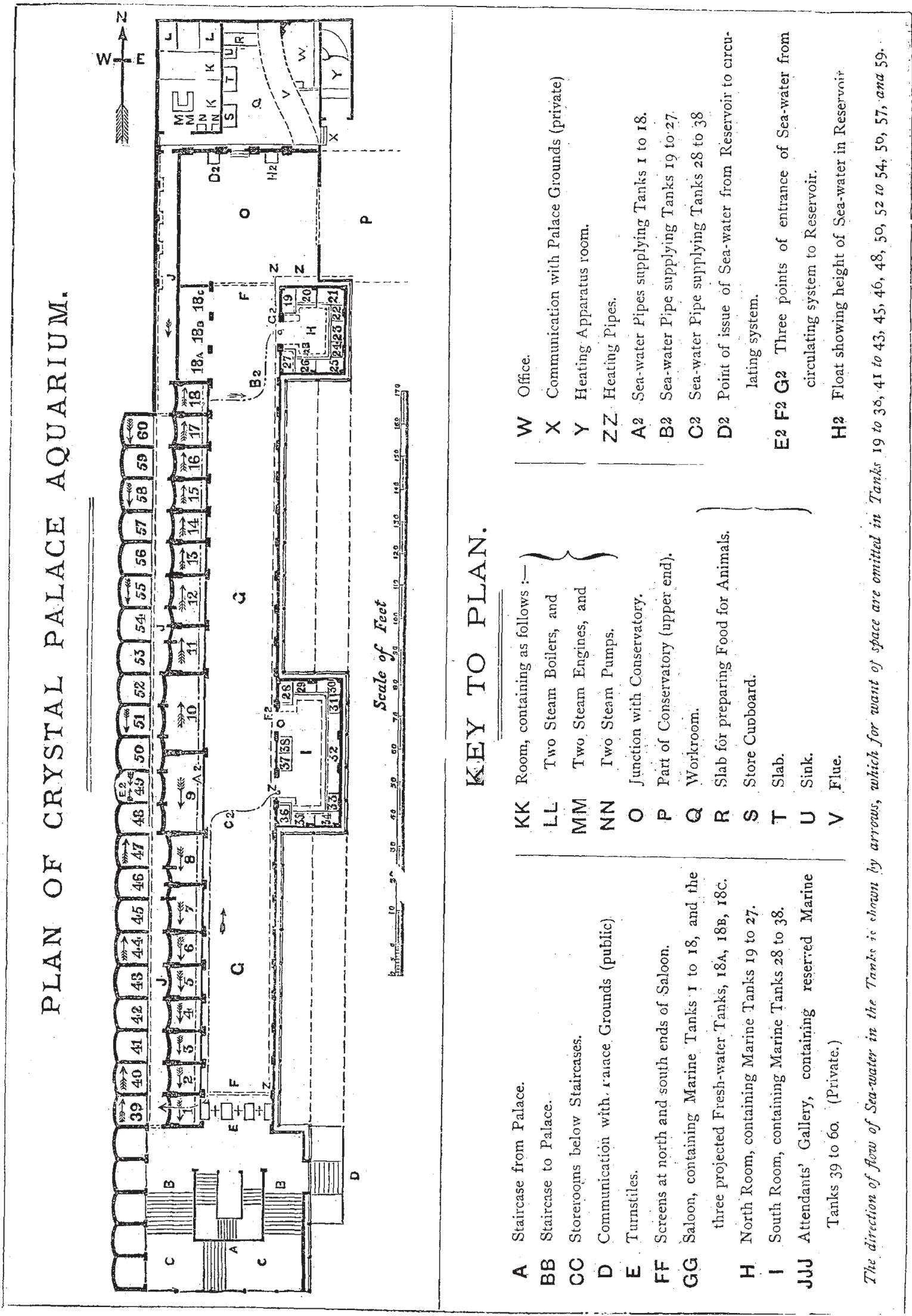


below the floor of the gallery $\mathrm{JJJ}$, and then the two currents converge centrally and fall together into the reservoir at tank 49. A portion of the water, however, is arrested above tank 9 , and is by separate pipes conveyed into the rooms $H$ and $I$, where, after circulating in the tanks 19 to 38 , it finds its way to the reservoir below at $\mathrm{F} 2$ and $\mathrm{G} 2$. Independently, however, of the simple fall of water from one tank to another in steps of from 3 to 6 inches in height in the series 1 to 18 (tanks 9 and Io being 6 feet high, while $I$ and 18 are 3 feet high-all internally), other streams of water, mixed with great quantities of air in minute bubbles, are driven from the main pipe into all the tanks with force. through jets, so that myriads of such bubbles, controlled by stopcocks, are forced in a state of fine division (resembling falling sand, or steam) nearly or quite down to the bottom of each tank, and thus the fluid is charged with as much ofmeric air as it will take up in open vessels. The amount of aëration (which also depends much on the amount of water entering) varies much, according to the dimensions of the tanks. Thus, tank to holds 4,000 gallons, and tank I holds 400 gallons, and, as tank Io has a stream equal to its own bulk running through it once an hour, it necessarily follows that as the same current flows through tank I (of only one-tenth the capacity of tank ro) then, tank I has a stream equal to its bulk, ten times as often as tank Io, that is to say, once every six minutes, and as these grades of aëration vary in all the tanks, they can be chosen according to the varying requirements of different kinds of animals. There is no intention to change the sea-water, but only to add from time to time a requisite quantity of distilled water to compensate for evaporation, and also to add whatever constituents the animals may deprive the sea-water of. For example, lobsters, crawfish, crabs, oysters, annelides with calcareous tubes, and many other animals, are constantly making new shells or adding to their old ones, and the matter is derived from the sea-water, and must be re-supplied.*

The material used for the pumps, stop-cocks, and jets, and for nearly all the pipes (the exceptions being the stoneware pipes connecting tanks 39 to 60 ) is vulcanite, or hard india-rubber. This was recommended by Prof. Faraday for the purpose in 1857 .

In tanks I to I 8 the creatures can be viewed only through the plate-glasses forming the fronts of the tanks; but in the twenty tanks of the rooms $H$ and I (Nos. I9 to 38 ), which are made to contain small spe? cimens, the view is through the surface of the water, as well as through the glasses of the fronts, as in the tablecases of a museum. The shallowness of these tanks, varying in water-capacity from 40 to 270 gallons each, much increases both their aëration and the accessibility of the objects they contain, and the much-shaded position of some of them, e.g., Nos. 19, 21, 25, 27, 28, 30,34, and 36 , affords means of maintaining some organisins, both animal and vegetable, needing an unusual amount of darkness. For example, no green algæ (Chlorosperms) will grow in the gloom of these tanks, while they are admirably suited for the Rhodosperms (or red algæ) which always flourish best in much obscurity. So, too, no direct sunlight can enter tank I, and as it contains only sea-anemones, it may be expected that this intentional ar angement will somewhat retard the usual fading of some of the colours of these animals when in aquaria. Tanks $I$ to 18 are lighted from a source not seen by spectators in front of the glasses.

In tanks 39 to 60 the view is only through the surface of the water. These twenty-two receptacles, each holding about 300 gallons of sea-water, contain, or are intended to contain, creatures which are at intervals drafted into the show tanks ( 1 to 38 ) and, acting as reserves and not for public inspection, they enable large numbers of animals to be purchased when they are to be cheaply and easily got, and thus these store-places in part remove the uncertainty of supply, which hitherto has attended inland marine aquaria. They are also used to keep living food, as mussels and shrimps, for the other animals.

For the general supply of the aquarium, the company possesses a large marine pond, in communication with the sea at every tide, and serving as a store, with a resident agent (Mr. C. Rogers), at Plymouth. This pond is capacious enough to furnish many animals, otherwise hard to be got, to all the public aquaria in Europe. The company has another agent (Mr. John Thompson) and store-place, at Southend, Essex ; and supplies are obtained also from Weymouth, from Mr. R. T. Smith; from Menai in North Wales, from Mr. E. Edwards; from Tenby, in South Wales, from Mr. W. Jenkins, together with other contributions from North and South Devonshire and the Channel Islands. Notwithstanding all these facilities, however, the difficulty of procuring animals in good health, and of sufnicient variety, and of right size, is very great-so great, indeed, on account of periods of excessive heat or cold, or rough weather, that there are probably not more than a dozen or fifteen weeks of any average year (with seldom a couple of weeks consecutively) in which animals can be most advantageously got, and this applies especially to fishes.

The animals at present in the aquarium are the following*:-Sea-anemones, fourteen species ; tube and other worms, six species; star-fishes, three species; seaurchins, lobsters, crawfish, edible-crabs, spider-crabs, swimming crabs, and various other crabs; prawns, two species; barnacles, oysters, mussels, cockles, and scallops; whelks, periwinkles, dogwinkles, and tops; cuttles, two species ; and many fishes, as skate, angel-fish, launce, pipe-fish, lump-fish, and sucking-fish ; sole, plaice, cod, whiting-pout, whiting, and rockling; wrasse, four species; goby, three species; blenny, three species; dragonet, gunnel, grey-mullet, sea-bream, sea-scorpion, two species ; pogge, gurnard, weever, and basse. All of these have to be fed constantly, many of them hourly, throughout the day, except on Sundays; and as for the seaanemones, of which there are already in the aquarium over 3,000 individuals, everyone of them has a morsel of food proportioned to its size given it at frequent intervals with a pair of wooden forceps, by an attendant whose sole occupation this is, as these flower-like creatures being so very non-locomotive as to be almost absolutely fixed, cannot pursue their food, or in an aquarium obtain it in any other manner, they being deprived of the actual ocean, every wave of which, when the animals are in a state of nature, bringing them nutriment which is arrested by their outspread and waving tentacles.

* Marine Animals in the Crystal Palace Aquarium, from August 20 to October 10, $187 x .-1$. Actinoloba dianthus. 2. Sagartia bellis. 3. Sagartia miniata. 4. Sagartia rosea. 5. Sagartia venusta. 6. Sagartia nivea. 7. Sagartia troglodytes. 8. Sagartia viduata. 9. Sagartia parasitica. 10. Anthea cereus. $\quad$ I. Actinia mesembryanthemum, r2. Bunodes Ballii. 13. Tealia cereus. II. Actinia mesembryanthemum, r2. Bunodes Ballit. I3. Tealia
crassiconnis. I4. Cerianthus Lloydii. 25. Uraster rubens. I6. Cribella crassicornis. I4. Cerianthus Liloydii. 25. Uraster rubens. I6. Cribella
oculata. I7. Solaster papposa. I8. Sipunculus Bernhardus. I9. Nemertes Borlasii. 20. Terebella conchilega. 2x. Sabella reniformis. 22. Sabella Borlasil. 20. Terebella conchilega. 2x. Sabella reniformis. 22. Sabella
unispira. 23. Terebella penicillus. 24. Sabella tubularia- 25. Serpula contortuplicata. 26. Serpula triquetra. 24 . Sabella tubularia- 25. Serpula con-
27. Spirorbis communis. 28. Gammarus locusta. 29. Palæmon serratus. 30. Palmon squilla. 3x. Crangon marus lousta. 29. Palæmon serratus. 30. Palæmon squilla. 3x. Crangon valgaris. 32. Homarus marinus. 33. Palinurus quadricornis. 34. Pagurus Beras. 35. Galathea strigosa. 36. Galathea squamifera. 37. Porcellana platycheles. 38. Pinnotheres pisum. 39 . Portunus puber. 40 Portunus depurator. 41. Carcinus Mænas. 42. Pilumnus hirtellus. 43 . Xanthis flonda. 44. Xanthis rivulosa 45. Cancer pagurus. 46. Maia Squinado. 47. Hyas araneus. 48. Inachus Dorsettensis. 49. Stenorhynchus phalangium. 50. Balanus balanoides. 5r. Lepas anatifera. 52. Ascidia mentula: 53. Cardium echinatum. 54. Mytilus edulis. 55 Anomia ephippium. 56. Eolis coronata. 57. Aplysia punctata. Purpura lapillus. 59. Buccinum undatum. 60 . Nassa reticulata. 6r. Murex erinaceus. 62. Sepiola Rondeletii. 63. Octopus vulgaris. 64. Raia batis. 65 . Squatina angelus. 66. Scyllium canicula. 67. Hippocampus brevirostris. 68. Syngnathus acus. 69. Ammodytes lancea. 7o. Anguilla acutirostris. 7r. Cyclopterus lumpus. 72 . Liparis vulgaris. 73. Solea vulgaris. 74. Platessa vulgaris. 75. Motella vulgaris. 76. Merlangus vulgaris. 77. Morrhua vulgaris. 78. Labrus maculatus. 79. Labrus mixtus. 80. Crenilabrus melops. 8x. Crenilabrus rupestris. 8z. Callionymus lyra 83. Gobius niger. 84. Gobius unipunctatus, 85. Gobius Ruthensparri 6. Bleunius pholis. 87. Blennius gattorugine. 88. Muræenoides guttata 9. Zoorces viviparus. 9o. Mugil capito. 9x. Pagellus centrodontus, $9^{2}$ 'rottus bubalis. 93. Cottus scorpius. 94. Asphidophorus cataphractus. 95 Criglia hirundo.

* The sean water was supplied in casks by $\mathrm{Mr}_{q} \mathrm{~W}_{\mathrm{H}} \mathrm{H}$ udson, of Brighton. 
The food consumed by a very few of the animals now present in the aquarium is vegetable, consisting of green seawceds (Ulva, Porphyra, Enteromorpha, \&c.), but by far the greater number have animal food given them. This consists of shrimps (alive or dead), crabs, milissels, oysters, and fish, but "butcher's meat" they never get. The large amount of organic matter thus continually (from 8 A.M. till 6 P.M. on six days a week) placed in the water, and the correspondingly great quantity of excrementitious matter resuiting from it, is nearly all rendered harmless by being decomposed chemically by the oxygenation of the streams of water, and by the growing vegetation, without the use of any fiter, and without the water being made turbid. In fact, the circulating system of the water in this aquarium is similar to, and avowedly made on the general model of, the circulating system of the blood of many of the animals which the aquarium itself maintains in life and health. Thus, the steam engine represents a heart, the coals consumed by the boilers are the food, the pipes are the veins and arteries, and the wide spreading air-charged streams of water discharged at the jets are the lungs.

Very few deaths occur, and the condition of the creatures will be further improved when the vegetation will have grown more. There are, however, reasons for supposing that not in any aquarium yet devised can any pelagic animals be permanently kept, and that therefore the bulk of specimens must be littoral creatures. But there are many marine animals and plants, both of the deep sea and the shore, which at present cannot be kept in captivity at all. The reason of this is in some cases known, but with others there is not the smallest clue as to the means to be adopted for their successful maintenance.

In front of tanks $x$ to 18 are placed obliquely, and over tanks 19 to 38 are suspended vertically, glazed frames to contain drawings of the animals. These pictures will be numbered to correspond with the numbered descriptive paragraphs of a guide-book now being prepared for the aquarium, so that any animal can be readily found. Although tank No. I contains exclusively sea-anemones, and thus properly commences with the lower animals, yet the classification of the creatures throughout the building is not made with reference to any acknowledged system founded on organisation, but the creatures are, so far as the limits of the place permit, arranged with reference to habits rather than struiture, and in such manner that, as much as possible, one animal shall not interfere injuriously with another.

The building is very cool in summer. Thus, during the hottest part of the season just passed through, when the true temperature of the general atmosphere in the shade was $88^{\circ} \mathrm{F}$., that of the air in the aquarium was only $68^{\circ} \mathrm{F}$, and the sea-water never rose higher than $63^{\circ} \mathrm{F}$. For winter, hot-water pipes are arranged to maintain the temperature of the air from $60^{\circ} \mathrm{F}$. to $65^{\circ} \mathrm{F}$.

The ventilation everywhere is remarkably good, and there is no tank in any of the entire series of sixty, which cannot be brought into free contact, when needed, with the open air.

The amount of daylight can also be very exactly regu lated ; and as, for the exhibition of the aquarium on winter evenings, it will be necessary to use powerful artificial illumination, some experiments are now being made on the best mode of lighting it, but it is not precisely known what will be the behaviour, in artificial light, of animals a great number of which are more or less nocturnal. Indeed, in an aquarium the difficulty ever is to show animals which endeavour to avoid being seen.

The architect; Mr. C. H. Driver, of Victoria Street (the builders being Messrs. Jackson and Shaw), *has shown much ingenuity in turning to good account every part of the space placed at his disposal, and in his simplicity of design he has not disobeyed any law of service in con-

* "Buildings for scientific purposes should be plain and useful above all things, in appearance as in fact."-PROF. RUSkIN. struction, in any case. Everytning is dol.c with a meaning, and with a definite and obvious purpose. Thus, as animals cannot exist with comfort without rock-work in the tanks, it has been plentifully introduced; but whatever picturesqueness of form it possesses, is merely a consequence of its being in the first place useful, and so strictly and severely is this principle carried out, that such rockwork does not project anywhere even an inch above the water's level, instead of being employed, as in most Continental aquaria, that of Berlin in particular, in the spectatcr's part of the building, inhere it is not wanted, and where, being perfectly useless, it is therefore ugly, and is merely an expensive excrescence. Everything in the Crystal Palace Aquarium is made to look like what it is, and not like something else, and not to pretend to be some other and more expensive material. Thus, if deal wood for its preservation is necessary to be painted, it is not also grained to look like oak or walnut-wood. Nor is cement squared withi mitation masonry joints, or otherwise treated so as to looklikestone. Nor is there any use of sham marble. It was certainly deemed advisable to make the building externally to correspond in general appearance with the arched and other iron framings which compose the Crystal Palace adjoining, and in which the glass of that edifice is set, but even then, this framing on the outside of the aquarium walls is employed usefully to strengthen those walls, which are purposely made insufficiently strong if such framing were absent. And wherever, either outside or inside the place, a little enrichment has been indulged in, it properly consists only in the decoration of construction, and not in the construction of decoration. Systematic economy in this Aquarium is in fact throughout observed in such manner that the largest number and variety of animals may be preserved in the best condition in the smallest space.

The two woodcuts on page 470 , each on a scale of half an inch to one foot, represent the pair of largest tanks, Nos. 9 and 1o, inhabited by crawfish and other crustaceans, and by wrasse, grey mullet, and other fishes. The front of each tank is composed of three pieces of glass, divided and supported at equal distances from either end by two large vertical mullions of slate and iron, and subdivided by three other and smaller vertical roulliciss of iron only. These six glasses, each measuring six feet square and one inch thick, are among the heaviest polished plates made in this country, by Messrs. Goslett and Co., and the wâter pressure on their aggregate surfaces amounts to 46,656 lbs., or nearly twenty;one tons.

\section{W. A. LLOYD}

\section{THE BIRDS OF THE LESSER ANTILLES*}

THE Lesser West Indian Islands, although mostly belonging to Great Britain and inhabited by a large number of intelligent colonists, and moreover easily accessible from our shores by a regular fortnightly line of packets, have hitherto been strangely neglected as regards their zoology. Of their botany we have an excellent account by Dr. Grisebach, published under the energetic superintendence of the authorities of the Herbarium at Kew. I am anxious to call the attention of the students of NATURE to what an interesting field here lies available for investigation,- particularly as regards the ornithology of these islands.

The West Indian Islands seem to me to constitute a distinct subdivision of the neo-tropical region, which may be called the Sub-regio Antillensis. This sub-region is divisible into two portions, which correspond to the two usually recognised divisions of the islands into the Greater and Lesser Antilles. The former of these is characterised by the presence of the remarkable mammal-forms Sole* Principally extracted from a paper read before the Zoological Society.
on March 21 , 187 I. 